\title{
OVIPOSITION SEQUENCE AND OFFSPRING OF MATED AND VIRGIN FEMALES OF Cotesia flavipes (HYMENOPTERA: BRACONIDAE) PARASITIZING Diatraea saccharalis LARVAE (LEPIDOPTERA: CRAMBIDAE)
}

\author{
SCAGLIA M. (1), CHAUD-NETTO J. (1), BROCHETTO-BRAGA M. R. (1), \\ CEREGATO S. A. (2), GOBBI N. (2), RODRIGUES A. (1)
}

(1) Department of Biology, Institute of Biosciences, São Paulo State University, UNESP, Rio Claro, São Paulo, Brazil; (2) Department of Ecology, Institute of Biosciences, São Paulo State University, UNESP, Rio Claro, São Paulo, Brazil.

\begin{abstract}
Large scale mass rearing of natural enemies has been a mean of improving biological control in the sugarcane intensive agriculture. Among them, Cotesia flavipes, a gregarious koinobiont endoparasitoid, was imported by Brasil to control caterpillars of the sugarcane borer Diatraea saccharalis. The $C$. flavipes larval development depends on its association with polydnavirus, which blocks the host defense reaction. To verify if the oviposition sequence $\left(1^{\text {st }}, 2^{\text {nd }}\right.$ or $\left.3^{\text {rd }}\right)$ and the female condition (mated or virgin) interfere in the number of $C$. flavipes descendents, $4^{\text {th }}$ instar caterpillars of $D$. saccharalis were parasitized. Analysis of the data showed that: a) there is an inverse correlation between the parasitism efficiency and the host reaction (encapsulation); b) the number of caterpillars parasitized by virgin females that released parasitoid larvae in the period from 12 to 15 days was higher than that of caterpillars parasitized by mated females; c) a slight difference between mated and virgin females in relation to the parasitim success was observed; and d) the number of encapsulated parasitoid larvae was higher than that of eggs, suggesting that eggs have a better capacity to overcome the host reaction. In this study, the viability of $C$. flavipes eggs and larvae in the non-specific host $D$. saccharalis could be correlated with the oviposition sequence and the female condition.
\end{abstract}

KEY WORDS: Cotesia flavipes, Diatraea saccharalis, oviposition sequence, encapsulation, chrysalises, parasitism.

\section{CORRESPONDENCE TO:}

M. R. BROCHETTO-BRAGA, Departamento de Biologia, Instituto de Biociências, UNESP, PO Box 199, 13506-900, Rio Claro, São Paulo, Brasil. Phone: + 55193526 4146. Fax: + 55193526 4136. Email: mrbbraga@rc.unesp.br 
M. Scaglia et al. OVIPOSITION SEQUENCE AND OFFSPRING OF MATED AND VIRGIN FEMALES OF Cotesia flavipes (HYMENOPTERA: BRACONIDAE) PARASITIZING Diatraea saccharalis LARVAE (LEPIDOPTERA: CRAMBIDAE). J. Venom. Anim. Toxins incl. Trop. Dis., 2005, 11, 3, p. 284

\section{INTRODUCTION}

Sugarcane (Saccharum officinarum) is a renewable energy source producer of sugar and alcohol. Its productivity depends on the quality and variety of seeds produced, soil management, and control of insect plagues. The sugarcane borer, Diatraea saccharalis, is the cause of the elevated damage to the sugarcane agriculture. Injury occurs by the mechanical action of the sugarcane borer building internal galleries, with consequent lateral budding, loss of weight, atrophy of culms, or apical bud death. In favorable conditions these galleries are contaminated by yeasts that cause red rottenness. Due to the simultaneous presence of all developmental stages of the plague throughout the year and the impossibility of using insecticides to control this borer, a biological control program was established in Brazil by releasing the parasitoid Cotesia flavipes, resulting in substantial increase of the sugar and alcohol productivity (5).

Cotesia flavipes is a gregarious koinobiont endoparasitoid that deposits its eggs inside the larvae hemocele with the ability to manipulate the host physiology in order to accommodate the development of its egg-larval stage. The intrinsic competition in the host-parasitoid system allows that the parasitoid overcome the defense system of its host. This competition depends on the parasitoid development rates, egg number, developmental stage of the host, oviposition order, and time interval between ovipositions (22). Studies performed to evaluate the number of $C$. flavipes ovipositions in $D$. saccharalis showed a difference in the number of released parasitoids from hosts parasitized once or twice. In this case, multiple parasitism was advantageous (33). Campos-Farinha and Chaud-Netto (9) observed that, in the same species, the number of parasitoids obtained from early instar caterpillars was lower in relation to those from the $5^{\text {th }}$ instar. Previous studies showed that no positive correlation was found among host lifetime, food consumption, and number of parasitoids released by the $4^{\text {th }}$ instar caterpillars of $D$. saccharalis firstly parasitized by mated females and later by virgin females of $C$. flavipes (14). The clutch size in gregarious parasitoids may be influenced by the amount and quality of nutritional resources. The rate of food consumption in the host increased with a corresponding increase in the parasitoid load, compensating the greater nutritional demand of the parasitoid (16). Biochemical and hormonal alterations also regulate the host metabolism, inducing substantial milieu conditions where the parasitoid larvae develop $(1,23)$. In Pseudaletia separata parasitized by Cotesia kariyai, one of these 
alterations could be provoked by a blocking peptide with repressive activity against juvenile hormone esterase (17). Braconids, like C. flavipes, produce polidnavirus (PDV) that are spread within the enlarged portion of both oviducts and replicate in the calyx cells nuclei. The viruses are released into the calyx lumen by cell lyses and apparently constitute a protective mechanism of eggs and larvae against the host reactions (30). In Venturia canescens the protective cover of the eggs is due to viruslike particles or PDV that are attached to the chorion surface. When injected into the host, the eggs that had these particles removed were encapsulated (2). Beyond these PDV, venom is also involved in immune suppression, provoking alterations in the morphology, behavior, and functions of hemocytes in hosts parasitized by Pimpla hipochondriaca (27). Host regulation factors can be divided into different categories according to their origin and function. The factors from maternal origin are produced by adult female parasitoids and are injected during oviposition (polydnavirus, venom, and ovarian proteins), effectively aiding eggs and larvae survival. Besides those, serosal membrane (teratocytes) embryonic factors have a strong impact on the host immune system and endocrine balance $(8,12,24)$. In Cotesia kariyai-Pesudaletia separata system, teratocytes had a fourfold increase in diameter and ploidy level during parasitism, being suggested that these teratocytes regulate the host physiological conditions (20).

The understanding of the relative performance of parasitoids from laboratory strains or the behavior of a non-specific host species is advantageous for planning biological control programs. The aim of this study was to verify the possible existence of a survival limit for Cotesia flavipes eggs and larvae in the non-specific host Diatraea saccharalis, which could be associated with the female condition (virgin or mated) and ovipositions sequence. The possible interference of other factors in parasitism success is also analyzed.

\section{MATERIAL AND METHODS}

This study was carried out in the Ecology Laboratory of the Biosciences Institute, São Paulo State University - Rio Claro. The insects (hosts and parasitoids) and the artificial diet were supplied by the Agricultural Laboratory of Sugar and Alcohol of Usina São João, Araras, São Paulo. The caterpillars of $D$. saccharalis were separated under stereomicroscope and subjected to parasitism in laboratory conditions $\left(25^{\circ} \mathrm{C}, 65 \pm 10 \% \mathrm{RH}\right.$, and mean luminosity of 1700 Lux). Males and 
females of $C$. flavipes copulated immediately after emergence. Each mated female, aged 4 hours or more, was released for the first oviposition in the $4^{\text {th }}$ instar caterpillars of $D$. saccharalis. After parasitism, each female was removed from the Petri dish in order to avoid the search for a $2^{\text {nd }}$ caterpillar and consequently the next parasitism. The same procedure was carried out to obtain the $2^{\text {nd }}$ and $3^{\text {rd }}$ ovipositions. After parasitism, the mated females were transferred to $15 \mathrm{ml}$ glass vials containing diluted honey (10\%), and the caterpillars were introduced into plastic boxes and fed on artificial diet. For each experimental group $\left(1^{\text {st }}, 2^{\text {nd }}\right.$ and $3^{\text {rd }}$ ovipositions) 10 repetitions were performed, totalizing 180 parasitized caterpillars.

The virgin females were separated, one by one, at emergence. The method of parasitism used for virgin females followed the same procedure adopted for mated females; 174 caterpillars were parasitized in the three ovipositions. An acclimatized room ( $28 \pm 2^{\circ} \mathrm{C}, 65 \pm 10 \% \mathrm{RH}$, and 12L-12D photoperiod) was used for maintenance of caterpillars and development of the parasitoids. Diurnal observations were done to remove dead caterpillars and chrysalises. The parasitoids were released from the hosts, weaved the cocoons, and then were transferred to $20 \mathrm{ml}$ glass vials for counting and sex identification. Caterpillars that did not originate parasitoids after 30 days were dissected for counting of eggs and encapsulated larvae. The $\chi^{2}$ test was used to evaluate significant differences between the data obtained from the experimental and control groups.

\section{RESULTS}

\section{Viability of Cotesia flavipes eggs and larvae and the oviposition sequence}

The overall capacity of $C$. flavipes protection of eggs and larvae was positively related to the $1^{\text {st }}$ oviposition, being recorded 1200 and 2137 adult descendents from mated and virgin females, respectively. The mean number of adult parasitoids per caterpillar from the $1^{\text {st }}$ oviposition was 36.36 for mated, and 32.87 for virgin females (Table 1). No significant differences between adults per caterpillar from the $1^{\text {st }}$ and $2^{\text {nd }}$ ovipositions were observed in both groups. In the $3^{\text {rd }}$ oviposition, the survival of parasitoids decreased dramatically; 246 and 266 parasitoids were recorded in the mated and virgin females group, respectively. On the other hand, in this oviposition, neither viable eggs nor larvae increased significantly (Table 1). Considering all ovipositions, 28 caterpillars parasitized by mated females and 15 by virgin ones died, but the cause of this death was not investigated in this study. Predatory action 
M. Scaglia et al. OVIPOSITION SEQUENCE AND OFFSPRING OF MATED AND VIRGIN FEMALES OF Cotesia flavipes (HYMENOPTERA: BRACONIDAE) PARASITIZING Diatraea saccharalis LARVAE (LEPIDOPTERA: CRAMBIDAE). J. Venom. Anim. Toxins incl. Trop. Dis., 2005, 11, 3, p. 287

(cannibalism) in both groups (13 caterpillars from mated and 14 from virgin females) was also observed. In this study, successful parasitism (development from egg to adult) was expressed as the proportion of parasitized caterpillars that effectively released adult parasitoids.

\section{Developmental period of parasitoids}

The developmental period between oviposition and parasitoids releasing from the $4^{\text {th }}$ instar Diatraea saccharalis caterpillars varied from 12 to 20 days, for both mated and virgin females of $C$. flavipes (Figure 1, Table 2). Almost all caterpillars released parasitoids from 12 to 15 days in the two tested groups. Nevertheless, in the period between 16 and 20 days the number of caterpillars parasitized by mated females that released parasitoids was greater (Figure 1) in relation to that recorded for the virgin females. A test of reciprocal independence was applied to the data from the parasitoids developmental period in relation to the oviposition sequence $\left(1^{\text {st }}, 2^{\text {nd }}\right.$ or $3^{\text {rd }}$ ) and female condition (virgin or mated). This analysis indicated that these variables are not independent $\left(\chi^{2}=71.58 ; p<0.05 ; \mathrm{DF}=7\right)$. A complementary test of partial independence using the same data indicated that the parasitoids developmental period depends on the female condition and also on the considered oviposition ( $\left.\chi^{2}=57.60 ; p<0.05 ; D F=5\right)$.

The developmental period for the male offspring of $C$. flavipes was slightly shorter in caterpillars that received ovipositions of virgin females in relation to those that were parasitized by mated females because the males generally emerge before the females.

There was not a significant difference in the number of adult parasitoids released per host in each oviposition in both groups tested (Table 1). The major number of parasitoids developed in caterpillars parasitized by virgin females was due to a minor mortality of hosts in this group. The results also showed that not all parasitized caterpillars released parasitoids in each oviposition. This fact was observed for 65 of the 84 hosts attacked by virgin females and 33 of the 60 caterpillars parasitized by mated females in the $1^{\text {st }}$ oviposition. The same occurred for 34 caterpillars parasitized by females of both groups ( $n=60$ for each group) in the $2^{\text {nd }}$ oviposition, and for only $14(n=60)$ and $13(n=30)$ hosts that received ovipositions of virgin and mated females, respectively. It was also verified that in the $1^{\text {st }}$ and $2^{\text {nd }}$ ovipositions the females searched the host, touched it with their antennae and then introduced the 
M. Scaglia et al. OVIPOSITION SEQUENCE AND OFFSPRING OF MATED AND VIRGIN FEMALES OF Cotesia flavipes (HYMENOPTERA: BRACONIDAE) PARASITIZING Diatraea saccharalis LARVAE (LEPIDOPTERA: CRAMBIDAE). J. Venom. Anim. Toxins incl. Trop. Dis., 2005, 11, 3, p. 288

ovipositor apparatus, whereas in the $3^{\text {rd }}$ oviposition the females spent more time to search and elect their hosts. The duration of each oviposition varied from 3 to 9 seconds with an average of 5.53 seconds.

\section{Chrysalises and host reaction (Encapsulation)}

Chrysalises: Comparing the three ovipositions, it was observed that, in the group of mated females, the number of non-parasitized caterpillars was greater than that of virgin females: 28 and 11 chrysalises, respectively (Table 3; Figure 2). In the $1^{\text {st }}$ and $2^{\text {nd }}$ ovipositions, the difference between both groups was not so drastic, while in the $3^{\text {rd }}$, the number of chrysalises was tenfold higher in the mated group. It can be suggested that the female capacity to select its host could be associated with the female condition (mated or virgin) or even with the host physiological conditions. If the host is not suitable for parasitism, it can be rejected.

Encapsulation: The number of caterpillars that recognized foreign eggs and/or larvae increased with the oviposition sequence. In the virgin females group, 3 caterpillars were observed in the $1^{\text {st }}$ oviposition, 7 in the $2^{\text {nd }}$, and 13 in the $3^{\text {rd }}$. Among the mated females, a higher number of caterpillars $(n=16)$ reacted to parasitism in the $2^{\text {nd }}$ oviposition, being recorded only 2 in the $1^{\text {st }}$, and 12 in the $3^{\text {rd }}$ (Table 3). A test of reciprocal independence applied to the data from the number of caterpillars that reacted to parasitism (or not) in relation to the oviposition sequence $\left(1^{\text {st }}, 2^{\text {nd }}\right.$ or $3^{\text {rd }}$ ) and female condition (virgin or mated) showed that these variables are not independent $\left(\chi^{2}=21.83 ; \mathrm{p}<0.05 ; \mathrm{DF}=7\right)$. A complementary test of partial independence using the same data indicated that the number of encapsulated parasitoids or the number of hosts that completed the development to chrysalis depends on the female condition and also on the oviposition considered $\left(\chi^{2}=19.90\right.$; $\mathrm{p}<0.05$; DF=5).

Encapsulation of parasitoids increased considerably in the $2^{\text {nd }}$ and $3^{\text {rd }}$ ovipositions. From 30 caterpillars parasitized by mated females, 11 eggs and 139 larvae encapsulated were found, while in the virgin females group, 23 caterpillars contained 6 eggs and 203 larvae encapsulated (Table 3; Figure 3). The mean number of encapsulated eggs was lower compared to that of larvae. The encapsulation of eggs and larvae also depends on the female condition (mated or virgin) and on the 
M. Scaglia et al. OVIPOSITION SEQUENCE AND OFFSPRING OF MATED AND VIRGIN FEMALES OF Cotesia flavipes (HYMENOPTERA: BRACONIDAE) PARASITIZING Diatraea saccharalis LARVAE (LEPIDOPTERA: CRAMBIDAE). J. Venom. Anim. Toxins incl. Trop. Dis., 2005, 11, 3, p. 289

oviposition considered $\left(\chi^{2}=85.41 ; p<0.05 ; D F=5\right)$. Many caterpillars parasitized by $C$. flavipes contained both encapsulated and non-encapsulated larvae.

Table 1: Diatraea saccharalis caterpillars parasitized by mated and virgin females of Cotesia flavipes in the $1^{\text {st }}, 2^{\text {nd }}$ and $3^{\text {rd }}$ ovipositions.

\begin{tabular}{|c|c|c|c|c|c|c|c|c|}
\hline & \multicolumn{4}{|c|}{ Mated females } & \multicolumn{4}{|c|}{ Virgin females } \\
\hline Oviposition & $\mathrm{N}$ & $\mathrm{C} / \mathrm{p}$ & Viab & Ad/mass & $\mathrm{N}$ & $\mathrm{C} / \mathrm{p}$ & Viab & Ad/mass \\
\hline $1^{\mathrm{st}}$ & 60 & 33 & 1200 & 36.36 & 84 & 65 & 2137 & 32.87 \\
\hline $2^{\text {nd }}$ & 60 & 34 & 1031 & 30.32 & 60 & 34 & 1101 & 32.38 \\
\hline $3^{\mathrm{rd}}$ & 60 & 14 & 246 & 17.57 & 30 & 13 & 266 & 20.46 \\
\hline Total & 180 & 81 & 2477 & & 174 & 112 & 3504 & \\
\hline
\end{tabular}

Table 2: Number of $D$. saccharalis caterpillars that released parasitoid larvae between 12 and 15 days or between 16 and 20 days in each oviposition $\left(1^{\text {st }}, 2^{\text {nd }}\right.$ or $3^{\text {rd }}$ ) of mated or virgin C. flavipes females.

\begin{tabular}{ccccc}
\hline & \multicolumn{3}{c}{ Mated females } & \multicolumn{2}{c}{ Virgin females } \\
\hline Oviposition & 12 to 15 days & 16 to 20 days & 12 to 15 days & 16 to 20 days \\
\hline $1^{\text {st }}$ & $31(27.02)$ & $2(5.98)$ & $60(53.21)$ & $5(11.79)$ \\
$2^{\text {nd }}$ & $17(27.83)$ & $17(6.16)$ & $33(27.83)$ & $1(6.16)$ \\
$3^{\text {rd }}$ & $5(11.46)$ & $9(2.54)$ & $12(10.64)$ & $1(2.36)$ \\
Total & 53 & 28 & 105 & 7
\end{tabular}

Numbers in parentheses are the expected frequencies under the null hypothesis for $\chi^{2}$ tests. 
Table 3: $D$. saccharalis caterpillars parasitized by mated and virgin females of $C$. flavipes in the $1^{\text {st }}, 2^{\text {nd }}$ and $3^{\text {rd }}$ ovipositions.

\begin{tabular}{ccccc|cccc}
\hline & \multicolumn{4}{c}{ Mated females } & \multicolumn{3}{c}{ Virgin females } \\
\hline Oviposition & Chrys & Clenc & Eg/enc & Larv/enc & Chrys & C/enc & Eg/enc & Larv/enc \\
$1^{\text {st }}$ & 5 & 2 & 4 & 0 & 5 & 3 & 1 & 9 \\
& $(2.97)$ & $(4.03)$ & $(0.19)$ & $(3.81)$ & $(3.39)$ & $(4.61)$ & $(0.47)$ & $(9.53)$ \\
$2^{\text {nd }}$ & 3 & 16 & 2 & 56 & 4 & 7 & 0 & 77 \\
& $(8.05)$ & $(10.94)$ & $(2.74)$ & $(55.25)$ & $(4.66)$ & $(6.34)$ & $(3.65)$ & $(73.35)$ \\
$3^{\text {rd }}$ & 20 & 12 & 5 & 83 & 2 & 13 & 5 & 117 \\
& $(13.56)$ & $(18.43)$ & $(4.17)$ & $(83.83)$ & $(6.36)$ & $(8.64)$ & $(5.78)$ & $(116.22)$ \\
Total & 28 & 30 & 11 & 139 & 11 & 23 & 6 & 203 \\
\hline
\end{tabular}

Chrys $=$ number of caterpillars that underwent metamorphosis; C/enc $=$ number of caterpillars that reacted to parasitism (encapsulation of eggs and larvae); Eg/enc = number of eggs encapsulated; Larv/enc $=$ number of larvae encapsulated. Numbers in parenthesis are the expected frequencies under the null hypothesis for $\chi^{2}$ tests.

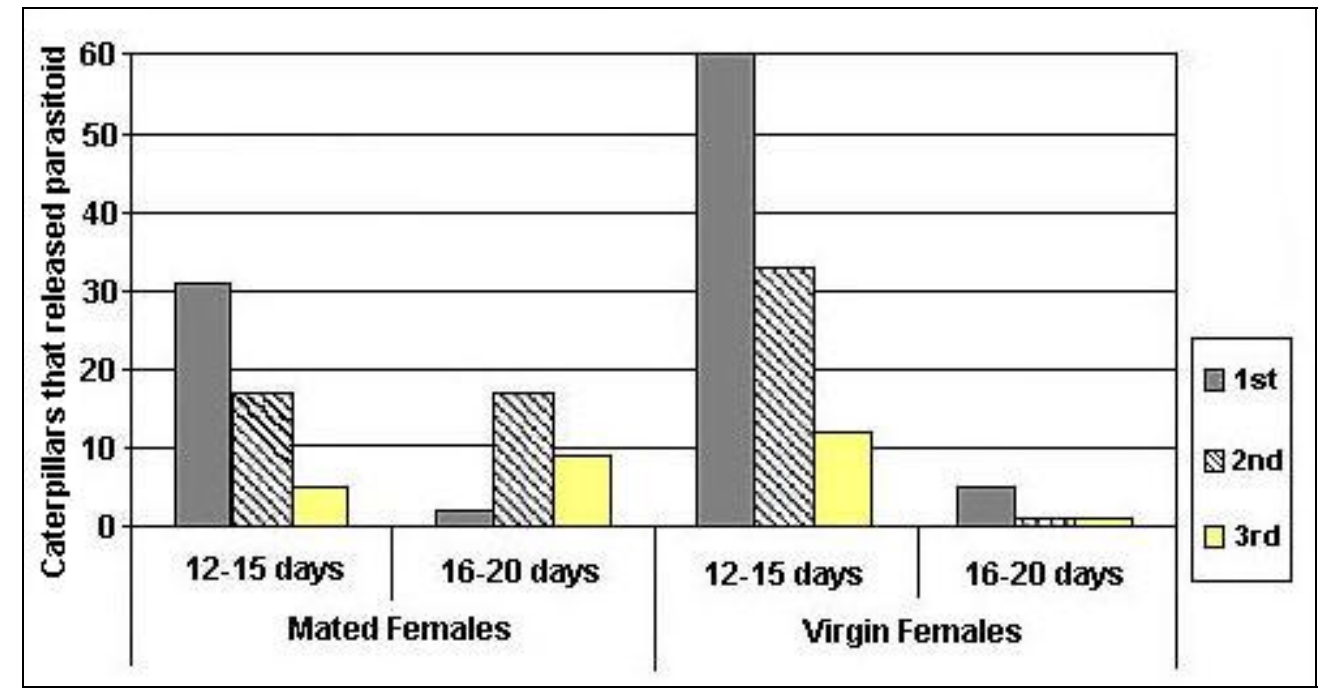

Figure 1: Number of $4^{\text {th }}$ instar caterpillars of Diatraea saccharalis parasitized in the $1^{\text {st }}, 2^{\text {nd }}$ or $3^{\text {rd }}$ oviposition of mated and virgin Cotesia flavipes females that released parasitoids in different periods. 


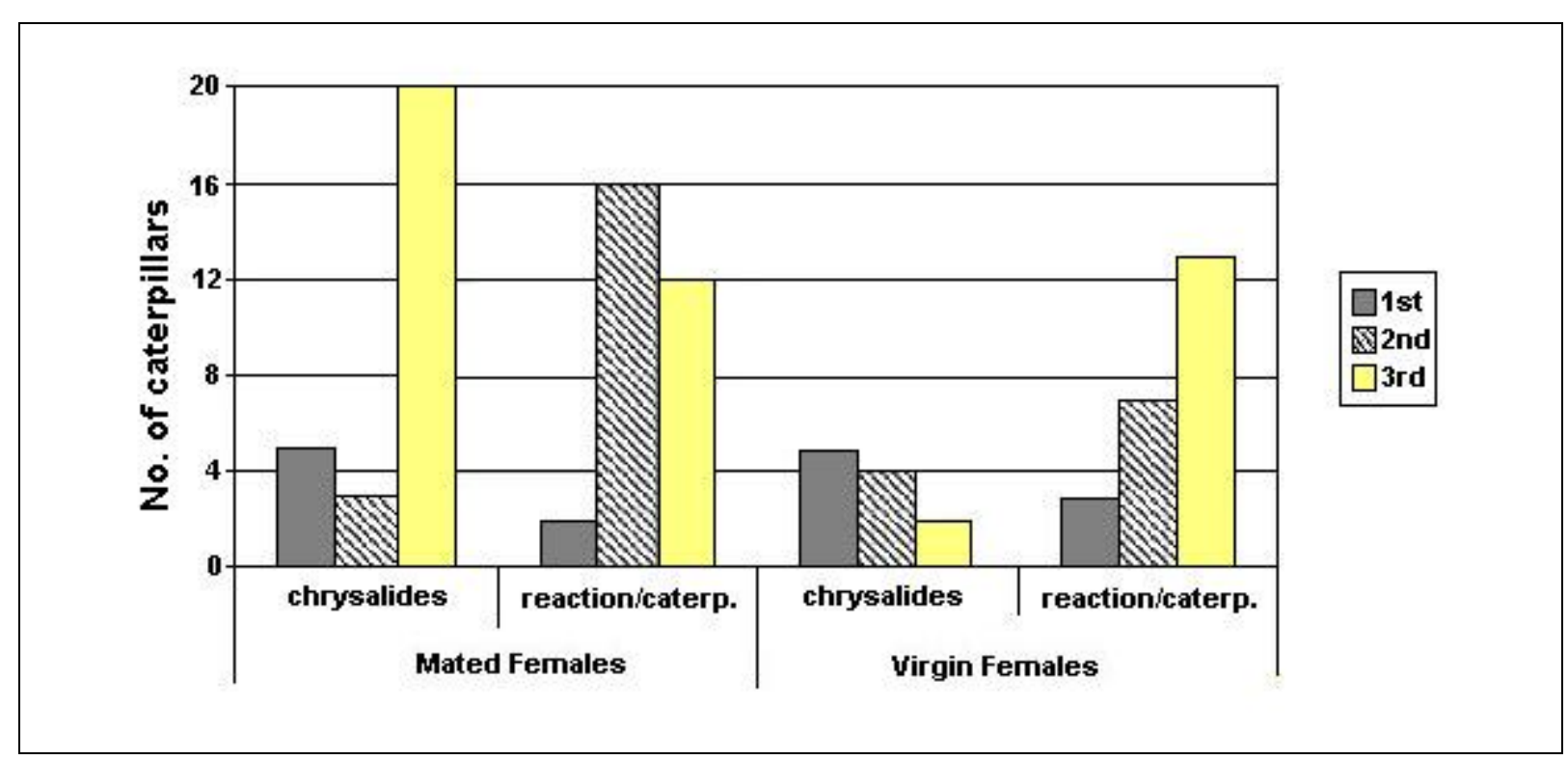

Figure 2: Number of Diatraea saccharalis caterpillars parasitized by mated and virgin Cotesia flavipes females that underwent metamorphosis (chrysalides), and number of hosts that encapsulated parasitoid eggs and larvae in each oviposition (reaction/caterp.).

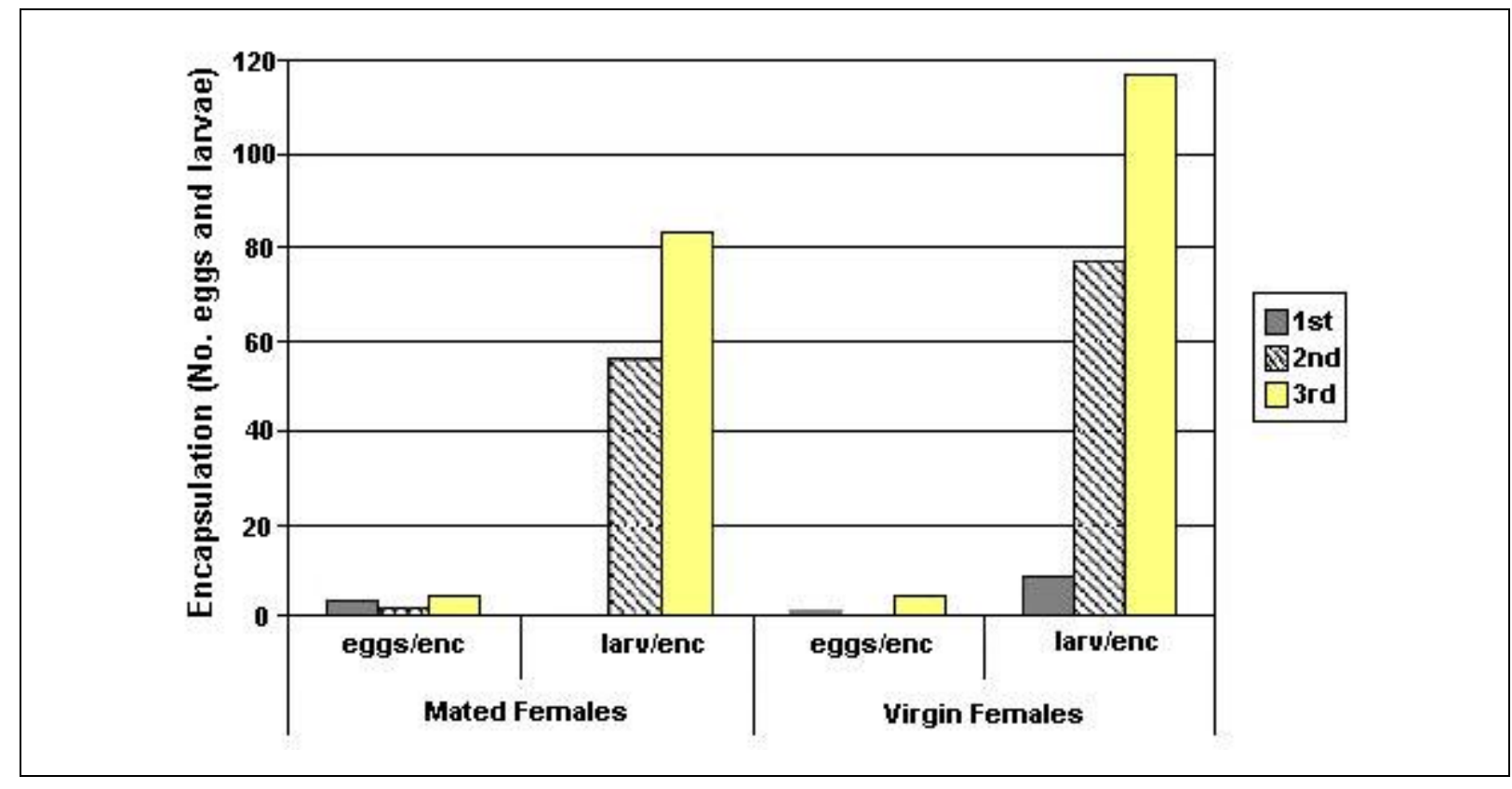

Figure 3: Number of eggs (egg/enc) and larvae (larv/enc) encapsulated by $4^{\text {th }}$ instar Diatraea saccharalis caterpillars parasitized by mated and virgin Cotesia flavipes females in the $1^{\text {st }}, 2^{\text {nd }}$ and $3^{\text {rd }}$ ovipositions. 
M. Scaglia et al. OVIPOSITION SEQUENCE AND OFFSPRING OF MATED AND VIRGIN FEMALES OF Cotesia flavipes (HYMENOPTERA: BRACONIDAE) PARASITIZING Diatraea saccharalis LARVAE (LEPIDOPTERA: CRAMBIDAE). J. Venom. Anim. Toxins incl. Trop. Dis., 2005, 11, 3, p. 292

\section{DISCUSSION}

The viability of eggs and larvae depends on their involvement in the host-parasitoid interactions, glandular secretions, and PDV injected during oviposition. Other factors introduced into the host during posture, such as venom (28) and ovarian proteins (32), may also be required, especially in the earliest stage before viral genes are expressed. Polydnavirus DNA replication apparently persists and is transcribed throughout the course of parasitism. In Microplitis demolitor, the polydnavirus DNA persisted for at least 6 days in its host and more viral DNA and RNA were detected in hemocytes than in other examined tissues (21).

The results obtained in this work showed that the eggs and larval development of $C$. flavipes in $D$. saccharalis also highly depends on the oviposition sequence and the female condition reinforcing the idea that, in the system Cotesia flavipes-Diatraea saccharalis, the number of descendents recorded in the $1^{\text {st }}$ oviposition is probably higher because the parasitoid eggs are involved by a greater number of PDV. The great number of encapsulated larvae recorded, mainly in caterpillars that received the $3^{\text {rd }}$ oviposition of virgin and mated $C$. flavipes females, reinforces this supposition. The time of the larval development is also correlated to several factors: instar, age, sex, weight, and number of ovipositions. Previous studies showed that the embryogenesis and the larval stage of $C$. flavipes were seasonally variable, being 9 days in the summer and 13 days in the winter. However, some hosts released parasitoids in a period of up to 20 days post-parasitism (11). In Microctonus aethiopoides the period of egg/larval growth reached 15 days (3). A developmental period of 9 days for Aphaereta minuta was observed when the eggs were deposited in the host larval stage; this species was considered able to cause sudden differences in the potential host size at the moment of oviposition, and to allocate more eggs in hosts with the best nutritional condition (29). The host body size is the main target for host selection by parasitoid females, and this trait has an influence on the clutch size and, if the female is mated, also on the offspring sex ratio (16). The developmental period of Campoletis sonorensis larvae in Heliothis virescens was 8 days (15), whereas in Winthemia fumiferanae, in late instars of Choristoneura fumiferana, it was about 0.5 day longer in female than in male host pupae, without any statistical differences between both sexes in relation to this characteristic (19). Females of Muscidifurax raptorellus spent 15-16 days to complete the development, independently of the clutch size, and the males emerged before the $15^{\text {th }}$ day from 
hosts containing clutches with three or more parasitoids. Furthermore, the growth of individual larvae is increasingly affected when there is a competition among siblings for nutritional sources in superparasitized hosts (16). In Dacnusa sibirica it was observed that the later the host instar is, the shorter its developmental period (10). For C. flavipes developed in Chilo partellus, the mean time of development from eggs to adult was 19.2 days in a single oviposition, but in superparasitized hosts, a prolonged developmental period occurred (25).

The development of a koinobiont endoparasitoid from parasitism to its final stage depends on the host suitability in early instars. Consequently, differences in the host growth rate may affect the developmental time of the parasitoid since oviposition up until the attainment of its adult stage. However, the parasitoid larvae must have a favorable fitness to reach these conditions (18).

Considering our results and the fact that each $D$. saccharalis caterpillar of the $4^{\text {th }}$ instar received only one oviposition $\left(1^{\text {st }}, 2^{\text {nd }}\right.$ or $\left.3^{\text {rd }}\right)$, we suggest that: a) the parasitoid investment was the same for the three ovipositions; b) the caterpillars with the best physiological conditions were selected by C. flavipes females (mated or virgin) in the $1^{\text {st }}$ oviposition, and consequently the development of their offspring was benefited.

In relation to the host metamorphosis to chrysalis we suggest that the female capacity to select its host could be associated with the female condition (mated or virgin) or even with the host physiological conditions. However, other factors have considerable influence on the host metamorphosis, such as specific period of parasitism (instar) and hormone applications, teratocytes, and calyx fluid $(28,31)$, besides the oviposition sequence and the female condition. In Pieris brassicae parasitized by Cotesia glomerata, the percentage of caterpillars that overcame or blockaded parasitization and developed to chrysalis was higher in the $4^{\text {th }}$ than in the $3^{\text {rd }}$ instar (4). Thus, additional studies are necessary to know which and how many factors are associated with the non-specific species Cotesia-Diatraea system studied here.

In this work, analyses of the $C$. flavipes- $D$. saccharalis system indicated that the encapsulation reaction depends on the oviposition considered. Encapsulation of parasitoids increased considerably in the $2^{\text {nd }}$ and $3^{\text {rd }}$ ovipositions, suggesting that, probably, the eggs and mainly the larvae from the $2^{\text {nd }}$ and $3^{\text {rd }}$ ovipositions did not receive enough amounts of the calix fluid components to induce changes in the defense mechanism of this host. In this specific case, the parasitoid efficiency to 
block the host reactions must be limited and would be associated to the quantity of polidnaviruses available, explaining the fact of a host that received the $3^{\text {rd }}$ oviposition containing both non-encapsulated and encapsulated larvae. It was proposed that only the viral component of the calix fluid is able to inhibit encapsulation of parasitoids in the host (13). Cotesia rubecola eggs are protected against the encapsulation reaction of the host Pieris rapae by a protein layer that is noncovalently attached to the egg chorion $(2,26)$. The absence of protection obtained by the eggs washing suggests that the calix fluid components provide a passive protection against the host defense, which is lost by the egg surface masking.

Other aspects related to the encapsulation process were also observed. For instance, in the system C. glomerata-Pieris brassicae, the proportion of encapsulated eggs increased with the caterpillars age (4). The encapsulation process is associated with the species, since encapsulation of $C$. glomerata, a gregarious and generalist parasitoid, was higher in Pieris rapae than in $P$. napi $(6,7)$. Furthermore, a possible factor of competition, expressed by physiological suppression, was also suggested in Heliothis virescens parasitized by Cardiochiles nigriceps, a solitary endoparasitoid (22).

The results obtained in this research showed that successful development of Cotesia flavipes in Diatraea saccharalis caterpillars depends on the oviposition considered $\left(1^{\text {st }}, 2^{\text {nd }}\right.$ or $\left.3^{\text {rd }}\right)$ and also on the female condition (mated or virgin). Therefore, in order to promote an efficient program of biological control, these variables must also be considered. Undoubtedly, C. flavipes is efficient to control the sugarcane borer. Nevertheless, it is very important to study each system in order to know their impact on an intensive agricultural system. On the other hand, an efficient biological control with native parasitoids found in their own ecosystem for each stage of sugarcane borer could maintain $D$. saccharalis bellow the damage level.

\section{ACKNOWLEDGMENTS}

We thank Dr. Vadim Viviani for his critical review of the earlier version of the manuscript. This research was developed with financial support of Conselho Nacional de Desenvolvimento Científico e Tecnológico (CNPq) - Process $n$ 142081/96-5. The insects (hosts and parasitoids) and the artificial diet were gently supplied by the Agricultural Laboratory of Sugar and Alcohol of Usina São João, Araras, São Paulo. 


\section{REFERENCES}

1 ADAMO SA., LINN CE., BECKAGE NE. Correlation between changes in host behaviour and octopamine levels The tobacco hornworm Manduca sexta parasitized by the gregarious parasitoid wasp Cotesia congregata. J. Exp. Biol., 1997, 200, 117-27.

2 ASGARI S., SCHMIDT O. Passive protection of eggs from the parasitoid, Cotesia rubecula, in the host, Pieris rapae. J. Insect Physiol., 1994, 40, 789-95.

3 BARRAT BIP., SUTHERLAND M. Development of teratocytes associated with Microctonus aethiopoides Loan (Hymenoptera:Braconidae) in natural and novel host species. J. Insect Physiol., 2001, 47, 257-62.

4 BAUER E., TRENECZEK T., DORN S. Instar-dependent hemocyte changes in shape Pieris brassicae after parasitization by shape Cotesia glomerata. Entomol. Exp. Appl., 1998, 88, 49-58.

5 BOTELHO PMS., PARRA JRP., CHAGAS-NETTO JF., OLIVEIRA CPB. Associação do parasitóide de ovos Trichogramma galloi Zucchi (Hymenoptera:Trichogrammatidae) e do parasitóide larval Cotesia flavipes (Cam.) (Hymenoptera Braconidae) no controle de Diatraea saccharalis (Fabr.) (Lepidoptera: Crambidae) em cana-de-açúcar. Ann. Soc. Entomol. Brasil, 1999, 28, 491-6.

6 BRODEUR J., GEERVLIET JBF., VET LEM. The role of host species, age and defensive behaviour on ovipositional decisions in a solitary and gregarious generalist parasitoid (Cotesia species). Entomol. Exp. Appl., 1996, 81, 12532.

7 BRODEUR J., GEERVLIET JBF., VET LEM. Effects of Pieris host species on life history parameters in a solitary specialist and gregarious generalist parasitoid (Cotesia species). Entomol. Exp. Appl., 1998, 86, 145-52.

8 BURON I., BECKAGE NE. Developmental changes in teratocytes of the Braconidae wasp Cotesia congregata in larvae of the tobacco hornworm, Manduca sexta. J. Insect Physiol., 1997, 43, 915-30.

9 CAMPOS-FARINHA AE., CHAUD-NETTO J. Biologia reprodutiva de Cotesia flavipes (Cam) II. Efeito de múltiplas cópulas sobre o número de posturas, razão sexual e larvas que emergem do hospedeiro Diatraea saccharalis (F.). Arq. Inst. Biol., 1998, 65, 57-61. 
M. Scaglia et al. OVIPOSITION SEQUENCE AND OFFSPRING OF MATED AND VIRGIN FEMALES OF Cotesia flavipes (HYMENOPTERA: BRACONIDAE) PARASITIZING Diatraea saccharalis LARVAE (LEPIDOPTERA: CRAMBIDAE). J. Venom. Anim. Toxins incl. Trop. Dis., 2005, 11, 3, p. 296

10 CROFT P., COPLAND MJW. The effect of host instar on the size and sex ratio of the endoparasitoid Dacnusa sibirica. Entomol. Exp. Appl., 1995, 74, 121-24.

11 CUEVA MC., AYQUIPA AG., MESCUA V. Estudios sobre Apanteles flavipes (Cameron), introducido para controlar Diatraea saccharalis (F.) en el Peru. Rev. Per. Entomol., 1980, 23, 73-6.

12 DIGILIO MC., ISIDORO N., TREMBLAY E., PENNACCHIO F. Host castration by Aphidius ervi venom proteins. J. Insect Physiol. , 2000, 46, 1041-50.

13 EDSON KM., VINSON BS., STOLTZ DB., SUMMERS MD. Virus in a parasitoid wasp: suppression of the cellular immune response in the parasitoid's host. Science, 1981, 211, 582-3.

14 GOBBI N., CHAUD-NETTO J., DINIZ-FILHO JAF., TORNISIELO SMT., ALMEIDA LC., NAZARETH, SL. Estudo do relacionamento entre Cotesia flavipes (Cameron) e Diatraea saccharalis (Fabricius). II. Efeito do parasitismo no consumo alimentar de lagartas de $5^{0}$ instar. Ann. Soc. Entomol. Brasil, 1994, 23, 45-9.

15 GUNASENA GH., VINSON SB., WILLIAMS HJ. Interrelationships between growth of Heliothis virescens (Lepidoptera: Noctuidae) and that of its parasitoid, Campoletis sonorensis (Hymenoptera:Icheneumonidae). Ann. Entomol. Soc. Am., 1989, 82, 187-91.

16 HARVEY JA., VET LEM., JIANG N., GOLS RJZ. Nutritional ecology of the interaction between larvae of the gregarious ectoparasitoid, Muscidifurax raptorellus (Hymenoptera: Pteromalidae) and their host pupal host, Musca domestica (Diptera: Muscidae). Physiol. Entomol., 1998, 23, 113-20.

17 HAYAKAWA Y. Structure of a growth-blocking peptide present in parasitized insect hemolymph. J. Biol. Chem., 1991, 266, 7982-4.

18 HEMERIK L., HARVEY JA. Flexible larval development and the timing of destructive feeding by a solitary endoparasitoid: an optimal foraging problem in evolutionary perspective. Ecol. Entomol., 1999, 24, 308-15.

19 HÉRBERT C., CLOUTIER C. Host instar as a determinant of preference and suitability for two parasitoids attacking late instars of the spruce budworm (Lepidoptera: Tortricidae). Ann. Entomol. Soc. Am., 1990, 83, 734-41.

20 HOTTA MT., OKUDA T., TANAKA T. Cotesia kariyai teratocytes: growth and development. J. Insect Physiol., 2001, 47, 31-41. 
M. Scaglia et al. OVIPOSITION SEQUENCE AND OFFSPRING OF MATED AND VIRGIN FEMALES OF Cotesia flavipes (HYMENOPTERA: BRACONIDAE) PARASITIZING Diatraea saccharalis LARVAE (LEPIDOPTERA: CRAMBIDAE). J. Venom. Anim. Toxins incl. Trop. Dis., 2005, 11, 3, p. 297

21 MILLER LK. Insect Viruses. In:. FIELDS BN., KNIP DM., HOWLEY PM. Eds. Fields Virology, 18. Philadelphia: Lippincott - Raven Publishers, 1996, 53356.

22 MORAES CM., CORTESERO AM., STAPEL JO., LEWIS WJ. Intrinsic and extrinsic competitive interactions between two larval parasitoids of Heliothis virescens. Ecol. Entomol., 1999, 24, 402-10.

23 PENNACCHIO FP., VINSON SB., TREMBLAY E. Growth and development of Cardiochiles nigriceps Viereck (Hymenoptera:Braconidae) larvae and their synchronization with some changes of the hemolymph composition of their host., Heliothis virescens (F.) (Lepidoptera: Noctuidae). Arch. Insect Biochem. Physiol., 1993, 24, 65-77.

24 PENNACCHIO FP., FALABELLA M., SORDETTI R., VARRICCHIO P., MALVA C., VINSON SB. Prothoracic gland inactivation in Heliothis virescens (F) (Lepidoptera: Noctuidae) larvae parasitized by Cardiochiles nigriceps Viereck (Hymenoptera:Braconidae). J. Insect Physiol., 1998, 44, 845-57.

25 POTTING RPJ., SNELLEN HM., VET LEM. Fitness consequences of superparasitism and mechanism of host discrimination in stemborer parasitoid Cotesia flavipes. Entomol. Exp. Appl., 1997, 82, 341-48.

26 PRÉVOST G., DAVIES DH., VINSON SB. Evasion of encapsulation by parasitoid correlated with the extent of host hemocyte pathology. Entomol. Exp. Appl., 1990, 55, 1-10.

27 RICHARDS EH., PARKINSON NM. Venom from the endoparasitoid wasp Pimpla hypochondrica adversely affects the morphology, viability, and immune function of hemocytes from larvae of the tomato moth, Lacanobia oleracea. J. Invert. Pathol., 2000, 76, 33-42.

28 TANAKA T. Physiological interactions between a host, Pseudaletia (Leucania) separata and its parasitoid, Microplitis mediator and Apanteles kariyai. Mem. Fac. Scien. Kyoto Univ., 1986, 11, 1-27.

29 VET LEM., DATEMA A., VAN WELZEN K., SNELLEN H. Clutch size in a larvalpupal endoparasitoid. Oecologia, 1993, 95, 410-5.

30 VINSON SB. How parasitoids deal with the immune system of their host: an overview. Arch. Insect Biochem. Physiol., 1990, 13, 3-27. 
31 WANI M., YAGI S., TANAKA T. Synergistic effect of venom, calyx and teratocytes of Apanteles kariyai on the inhibition of larval pupal ecdysis of the host, Pseudaletia separata. Entomol. Exp. Appl, 1990, 57, 101-4.

32 WEBB BA., LUCKHART S. Evidence for an early immunosuppressive role for related Campoletis sonorensis venom and ovarian proteins in Heliothis virescens. Arch. Insect Biochem. Physiol., 1994, 26, 147-63.

33 YAMAUCHI MN., GOBBI N., CHAUD-NETTO J., CAMPOS-FARINHA AE. Relationship between number of ovipositions of Cotesia flavipes (Cam.) and number of descendents emerged from its host Diatraea saccharalis. Ann. Soc. Entomol. Brasil, 1997, 26, 87-91. 